Article

\title{
Stopping Mass Atrocities: Targeting the Dictator
}

\author{
Maartje Weerdesteijn \\ Department of Criminal Law, Tilburg University, 5000 LE, Tilburg, The Netherlands; E-Mail: m.weerdesteijn@uvt.nl
}

Submitted: 9 May 2015 | In Revised Form: 18 June 2015 | Accepted: 30 June 2015 |

Published: 27 October 2015

\begin{abstract}
The international community has determined it carries the responsibility to protect civilians from atrocity crimes if a state is unable or unwilling to do so. These crimes are often perpetrated in authoritarian regimes where they are legitimized through an exclusionary ideology. A comparative case study of Pol Pot and Milosevic indicates that whether the leader truly believes in the ideology he puts forward or merely uses it instrumentally to manipulate the population, is an important variable, which affects the manner in which third parties can respond effectively to these crimes. While Pol Pot was motivated by his ideological zeal, Milosevic used ideology to create a climate in which mass atrocities could be perpetrated in order to garner further power and prestige. In Max Weber's terminology, Milosevic was guided by instrumental rationality while Pol Pot acted on the basis of value rationality. This case study compares two crucial moments-Vietnam's invasion of Cambodia and NATO's bombing of Serbia when the crisis in Kosovo escalated-to analyze the responsiveness of the two leaders. It is argued that ideological leaders are less responsive than non-ideological leaders to foreign policy measures targeted to stop or mitigate the occurrence of atrocities.
\end{abstract}

\section{Keywords}

dictator; foreign policy; mass atrocity; Pol Pot; rationality; Slobodan Milosevic

\section{Issue}

This article is part of the special issue "Mass Atrocity Prevention", edited by Professor Karen E. Smith (London School of Economics and Political Science, UK).

(C) 2015 by the author; licensee Cogitatio (Lisbon, Portugal). This article is licensed under a Creative Commons Attribution 4.0 International License (CC BY).

\section{Introduction}

Pol Pot and Slobodan Milosevic have orchestrated the perpetration of horrendous atrocities until foreign powers intervened to prevent them from doing so any further. The crimes which were perpetrated in Cambodia from 1975 until 1979 only ceased when Vietnam deposed Pol Pot from power and the atrocities which were inflicted by Milosevic's regime in Kosovo in 1999 only stopped after NATO intervened with a large scale bombing campaign. In both situations the humanitarian motivations of the intervention are questionable but they likely prevented much more suffering in the long term (Bazyler, 1987, p. 608; Roberts, 1999, p. 108). These situations raise important questions in relation to mass atrocity prevention and the role foreign powers play in mitigating their occurrence. Looking at these case studies in comparative perspective provides important insights on a key factor which influences whether pressure from the international community is successful, namely the willingness of the leader to change its policy and stop the perpetration of atrocities. There are striking similarities between the case studies that make for an interesting comparison. Both foreign powers tried to come to a peace agreement before resorting to military intervention (Bellamy, 2001; Burchett, 1981, pp. 148, 160) and both of the leaders faced much stronger forces (Daalder \& O'Hanlon, 2000, p. 140; Womack, 2003). However, there is also one crucial difference; while Milosevic eventually was willing to reach a peace agreement with NATO, Pol Pot fought until the bitter end.

Both cases have been studied extensively, but due to the extremely secretive nature of Pol Pot's regime, 
much less information is available on the situation in Cambodia, and more specifically on Pol Pot and his decision making process, than there is about Milosevic and his rule throughout the 1990 s. $^{1}$ While this is undoubtedly reflected in the analysis below, it will be argued that there is sufficient knowledge to analyze what ultimately influenced Pol Pot's decision making process and how this contributed to Pol Pot's unwillingness to yield to pressure from foreign powers, most notably Vietnam.

While the article focuses on the case studies mentioned above, its findings might be relevant for other situations in which the international community aims to mitigate mass atrocities. In 2005 , the international community determined it carries the responsibility to protect civilians from atrocity crimes if a state is unable or unwilling to do so. Yet with so many attempts to stop mass atrocities failing miserably for a variety of reasons, it seems worthwhile considering why these leaders made such different choices when they faced military intervention.

Increasingly, scholars have come to believe that the role the individual decision maker plays in determining the course of action of a particular regime deserves more attention (Byman \& Pollack, 2001; Hagan, 2001; Hermann \& Hagan, 1998; Hermann, Preston, Korany, \& Shaw, 2001). When scholars analyze the individual as a decision making unit it is often assumed that individuals act on the basis of a rational consideration, even when this is bounded by human cognition and emotions (Hanoch, 2002; McDermott, 2004b; Mercer, 2005; Mintz \& DeRouen, 2010; Rosati, 2000; Simon, 1985). This perspective, however, is unable to accommodate the role ideology plays in the decision making process (D'Avray, 2010, pp. 2, 29-31, 43-46). This is especially problematic when the causes of mass atrocities are analyzed since ideology plays an important role in motivating and instigating the atrocities (Alvarez, 2008). Therefore, a more nuanced perspective on rationality is required. Using the work of Max Weber it is argued that a different perspective on rationality, which takes into account the role that ideology may play, can provide additional insights in the decision making process.

Firstly, the role of dictators and ideology in motivating and instigating mass atrocity is examined. By analyzing the situations in Cambodia and the region which was formerly known as Yugoslavia ${ }^{2}$, it will be argued

\footnotetext{
${ }^{1}$ For an overview of the academic debate regarding both case studies see Kiernan (2010) on Cambodia and Ramet on the wars that led to the dissolution of Yugoslavia (2005).

2 When I refer to "Yugoslavia" I mean the region which existed between 1918 and 1991 under different names. After Yugoslavia started to fall apart, the roles of the different subregions becomes more important for the analysis, and therefore the article refers in those instances to particular regions by their name e.g. Serbia or Kosovo.
}

that the leader plays an important role in transforming a situation in which atrocities may be committed, to one in which they are actually perpetrated, thus justifying a focus on the leader when efforts are undertaken to bring these crimes to a halt. The section thereafter focuses on the role of the individual and his rationality in the foreign policy decision making process. The rationality of Pol Pot and Milosevic will subsequently be examined after which an assessment will follow on how this influenced their decision making process when Vietnam and NATO threatened to intervene.

\section{Dictators and Mass Atrocity}

There were many pre-conditions, which heighten the risk of mass atrocities, present in Cambodia and Yugoslavia. It was each of these leaders, however, that managed to transform these preconditions into a situation in which these crimes were actually perpetrated.

\subsection{Preconditions and the Role of the Leader}

Several authors have suggested that the most important preconditions are a non-democratic system of government (Fein, 1995; Krain, 2000; Regan \& Henderson, 2002; Rummel, 1994) ${ }^{3}$, difficult life conditions because of economic or political crises or war (Alvarez, 2001, pp. 68-71; Shaw, 2007, pp. 104-105; Staub, 2000, pp. 369-370; Wayne Nafziger \& Auvinen, 2002; Woolf \& Hulsizer, 2005), pre-existing schisms among different groups in the population and a history of past atrocities (Harff, 2003; Kuper, 1981; Staub, 2000, pp. 369-372). ${ }^{4}$

A non-democratic leader has less restraints to prevent him from perpetrating mass atrocities (Ezrow \& Frantz, 2011, pp. 149-151; Kinne, 2005). He may use the state's resources to influence a nation's collective memory and manipulate the narrative to transform historical enemies into those that have contemporary relevance (Chirot \& McCauley, 2010, pp. 64-65; Smeulers \& Grünfeld, 2011, pp. 248-249; 265; Woolf \& Hulsizer, 2005, pp. 106-109). In addition, he may use economic and political upheaval and redirect the discontent of the population towards particular vulnerable groups (Staub, 1989, pp. 48-49; 2010, p. 174). Finally, the leader may be instrumental in setting up the institutions which facilitate the process of perpetrating atrocity crimes. In this sense, the leader often plays a

\footnotetext{
${ }^{3}$ While some authors argue all dictatorships are more prone to commit atrocities, others argue that this is more likely in weak regimes when they are in the process of becoming more democratic. Most scholars agree, however, that stable democracies are least likely to perpetrate these crimes, making the authoritarian nature of a regime-regardless of whether it is weak or strong-an important risk factor.

${ }^{4}$ For an overview of the most important preconditions that have been identified see Harff (2003).
} 
very important role in inciting and instigating mass violence. In the next two sections it will be explained how Pol Pot and Milosevic played such an important role in their respective country.

\subsection{Pol Pot in Cambodia}

Pol Pot played a crucial role in inciting and legitimizing the crimes that were perpetrated in Cambodia. The country had always been known as the "gentle land" but it had its own troubled history (Jones, 2006, p. 185; Vickery, 1984, p. 7). Cambodia was once home to the great Khmer speaking kingdom Ankor but it crumbled after the $15^{\text {th }}$ century through numerous foreign invasions mostly stemming from its more powerful neighbors Thailand and Vietnam (Chandler, 1998, p. 12; Peang-Meth, 1991, p. 443). The country thereafter became subject to French colonial hegemony, the repressive regime of Sihanouk and eventually Pol Pot rose to power in the wake of heavy American bombing, an economic downturn and through a brutal civil war (Chandler, 2008; Vickery, 1984). By this time, the distraught population in the countryside, which had suffered disproportionately from all the hardship and felt exploited by the more prosperous urban population, were highly susceptible to the message of equality the Khmer Rouge brought to their homes (Hinton, 1998, p. 363; Vickery, 1984, p. 25).

\subsubsection{Using Ideology to Legitimize the Crimes and Redirect Anger}

The ideology of Pol Pot and the Khmer Rouge was rooted in this history. The anti-Vietnamese sentiment that was propagated by the elite stemmed partly from the country's historical subjugation (Chandler, 1979, p. 413; Takei, 1998, pp. 60-62). Traditionally most of the Sino and Vietnamese minorities had lived in the cities and as soon as Pol Pot rose to power he ensured that the cities were emptied to avoid further foreign influence, while at the same time dispersing potential opposition (Jackson, 1989, pp. 46-47). In addition, they hoped that emptying the cities would help them to improve the production of rice (Jackson, 1989, p. 48). The Khmer Rouge lived under the mistaken assumption that it had been water management and rice production which underlay the success of the Khmer nation in Ankorean times (Kiernan, 1996, p. 8; Straus, 2001, pp. 54-55). Becker explains how Pol "was preoccupied with returning Cambodia to its rightful place as the descendant of the Ankor Empire" (Becker, 1998, p. 121) and he is quoted as having said "If our people can build Ankor, they are capable of anything" (Chandler, 2008, p. 298). Pol Pot sought to accommodate old traditions and belief systems within his revolutionary ideals (Becker, 1998, pp. 60-61). Under his leadership the Khmer Rouge sought to reclaim land that was tradi- tionally thought to be Cambodian, the Kampuchea Krom region, but which had been in Vietnamese hands since 1840 (Chandler, 2008, p. 97; Jones, 2006, p. 186).

Pol Pot also relied heavily on the pre-existing animosity between the rural and the urban population. All of the country's problems before the revolution were blamed on the urban classes (Edwards, 2004, pp. 5960 ; Hinton, 1998, p. 363). Pol understood whom his audience was and the prejudices they held, and deliberately directed his message to the peasants because he knew they were more susceptible to it than the bourgeoisie (Becker, 1998, p. 122). After he got into power the urban population came to be seen as enemies of the people that needed to be crushed (Edwards, 2004, p. 59; Hinton, 1998, p. 363).

Next to these preexisting cultural proclivities that Pol Pot used, much of the Communist ideology was inspired by other communist regimes, most notably China and the Soviet Union. Pol Pot just sought to implement it more drastically and more rapidly than all the other regimes had done, to counter those elements which had prevented a perfect transition in those societies (Midlarsky, 2005, p. 320; Quinn, 1989b, pp. 219240). Pol Pot said he was "building socialism without a model", although he recognized being inspired by the thought of Mao Zedong (Becker, 1998, p. 185; Chandler, 2008, p. 256; Morris, 1999, p. 70). In reality, however, he seems to have been heavily influenced by the Chinese and within these modern communist theories sought to accommodate traditional Cambodian animosities (Becker, 1998, pp. 121-122).

\subsubsection{Institutions}

The Khmer Rouge indoctrinated mainly the young and impressionable through propaganda and harsh, often brutal, training techniques (Quinn, 1989a, pp. 237-239). They were seen as "a blank page", and were sought out because they were pure and receptive to the ideology (Hinton, 1998, p. 363; Midlarsky, 2005, p. 316). In addition, Pol Pot sought out minority groups (particularly from the Northeast) that he knew had grievances which could be exploited (Quinn, 1989a, p. 236).

He used violence against enemies from outside of the country, particularly the Vietnamese, while continuously purging his own party ranks (Quinn, 1989b, p. 180). Most of the latter victims were sent to detention centers such as Tuol Sleng prison which in fact was more of an extermination center than a prison (Fawthrop, 2005, p. 78). Much of the other violence against the population was perpetrated when the cities were emptied and throughout Pol's reign in the communes where the aim was to destroy the old society to create a communist utopia and destroy anyone who might stand in the way of this transformation (Quinn, 1989b). In this institutional set up both victims and perpetrators were thus forced to accept the ideology 
and conform to the pre-existing beliefs of the Khmer Rouge. Victims were forced to confess and thus confirm the existence of enemies in society while the perpetrators were indoctrinated and forced to accept the new worldview (Fawthrop, 2005, p. 78; Quinn, 1989a, pp. 237-239).

\subsection{Milosevic in Yugoslavia}

Milosevic, too, used already existing preconditions to create a situation in which atrocities were actually committed. After the death of Josip Broz "Tito", Yugoslavia faced an economic downturn, a political power vacuum emerged and the end of the Cold War eroded the country's prestigious position as the head of the non-aligned movement, causing the population to become susceptible to the message of new political leaders (Fine, 2006, p. 309; Jovic, 2001, p. 101; Woodward, 1995, pp. 15-17). Noticing how the nationalist rhetoric of Serbian intellectuals resonated with the population, Milosevic decided to use this message to expand his own power. In doing so he contributed to the dissolution of Yugoslavia (Kollander, 2004, pp. 7-8).

\subsubsection{Using Ideology to Legitimize the Crimes and Redirect Anger}

During Milosevic's reign, he used the media to strengthen his own support base and legitimize his policies (Brosse, 2003, p. 5). In his propaganda campaign the history of the Serbian nation was reinterpreted. After Tito's death, his legacy of brotherhood and unity were cast aside and replaced with a more divisive ideology (Jović, 2004, pp. 101-102). A landmark moment in this process was the publication of the SANU memorandum which was leaked to the press. It used the nation's past to foster tensions between different groups in the population. It gave the battle of Kosovo of 1389, that was of mythological importance to the Serbian nation, renewed relevance by drawing parallels between the injustice suffered by the Serbs on the battlefield and the manner in which the Serbian inhabitants of Kosovo were being treated by the Albanian population in more recent decades (Kollander, 2004, p. 8; Morus, 2007a, pp. 149-152). It also resurrected memories of WWII to enflame tensions between the different nations and suggested that the present difficulties Serbs experienced were a mere continuation of their victimization during this time (Morus, 2007a, p. 150).

There is reason to believe that the memorandum was created in collusion with nationalist politicians (Brosse, 2003, pp. 37-38). Milosevic was one of the politicians who used the rhetoric of the memorandum, and the outrage it sparked among the Serbian population, to his own advantage. This became most evident in two speeches, in 1987 and 1989, he held at Kosovo Polje which were widely broadcasted in the media and transformed Milosevic into a unifying force and savior of the Serbian people, thus cementing his power within the party (Brosse, 2003, p. 40; Morus, 2007b, p. 9). During the later speech, Milosevic presented the decision to end Kosovo's autonomy as "late justice" for those who had sacrificed themselves in battle 600 years earlier (Bieber, 2002, pp. 101-102). In this manner he used the already existing history and myths of the Serbian people to advance his own political goals. Serbia's population listened, because his message resonated with them and because Milosevic took charge of their discontent and gave it a direction. He demonized the other nations to unify his own.

\subsubsection{Institutions}

Milosevic armed Serbs outside of Serbia in the early 1990s and coopted key figures in the Yugoslav army (JNA) (Judah, 2009, pp. 169-170). However, the JNA was plagued by demoralized soldiers and as discipline started to wane, paramilitary groups were erected to supplement the regular forces (Cohen, 2006, pp. 468469; Mueller, 2000, p. 43). Milosevic pragmatically formed their ranks by emptying the prisons and by recruiting football hooligans and unemployed men willing to plunder (Alvarez, 2006, p. 9; Ron, 2000, p. 297). Milosevic relied on these individuals to commit most of the atrocities and this arrangement conveniently also provided him with "plausible deniability" (Kaldor, 2006, pp. 55-57; Ron, 2000, p. 293). These units were used throughout the wars in the early 1990s and again when violence erupted in Kosovo (Stewart, 2007, pp. 260-261).

\section{Ideology and the Decision Making Process}

Ideology is thus used by dictators to incite and instigate the crimes, but this does not mean that they actually believe in the message they propagate themselves. Some might be genuine believers while others will simply use it instrumentally. These distinctions however are lost in contemporary theories on the decision making process of individuals in the foreign policy arena. Foreign policy analysis does not sufficiently take the role that ideology plays in the decision making process into account.

\subsection{Rationality, Ideology and Foreign Policy Decision Making}

Numerous factors determine the foreign policy that a country will pursue but several scholars have placed renewed emphasis on the role the individual leader plays (Byman \& Pollack, 2001; Hermann \& Hagan, 1998; Hermann et al., 2001). Dictatorial leaders in particular wield much influence, often making them what Hermann et al. call a "predominant leader" (Hermann et al., 2001, pp. 84-85). 
Foreign policy decision-making literature has made great strides in pointing out the limits of the rational decision making processes of these individuals. Limits result from the human capabilities to calculate all options rationally, stem from biases and the decision making process can be distorted by emotions (Marcus, 2000; McDermott, 2004a; Mintz \& DeRouen, 2010; Renshon \& Renshon, 2008; Rosati, 2000). ${ }^{5}$ Considering these limits, it has been argued it is more useful to speak of bounded rationality (Simon, 1985).

Research on the conscious decision making process of individuals, nevertheless, still assumes individuals seek to attain particular preferences if the costs are not too high. The problem with this conceptualization is that it leaves little room for the role ideology may play. Ideology is not the same as a preference because it may cause people to behave in a certain way that actually goes against their preferences (D'Avray, 2010, pp. 2; 29-31; 43-46).

This oversight may be remedied by acknowledging that there are different kinds of rationality, as Max Weber has done. Weber identified four types of social action-action which is oriented to the behavior of others-two of which are rational (Weber, 1964, pp. 113-115). The typology is composed of instrumental rational action, value rational action, action which has an affectual orientation and a last type of action which stems from "habituation or long practice" (Weber, 1964, p. 115). What primarily separates the latter two types from the rational variants of social action is the conscious or voluntary nature of the rational variants, the idea that they are not done unthinkingly (Eisen, 1978, p. 59; Swidler, 1973, p. 38). Since the focus of this article will be on the conscious decision making process of leaders, the focus here will be on the first two types of action.

The first type of rationality, instrumental rationality, resembles what we commonly associate with rational action. According to Weber it is oriented to a "system of discrete individual ends" (1964, p. 115) and in the decision making process the "end means and secondary results are all rationally taken into account and weighed" (Weber, 1964, p. 117). Alternative means may be considered as well as the alternative consequences of the means used, and the relative importance of different ends (Weber, 1964, p. 117). Priorities may be shifted, and goals may be abandoned when the costs get too high (Varshney, 2003, p. 86).

The second type of rationality is oriented to "a conscious belief in the absolute value of some ethical, aesthetic, religious, or other form of behavior, entirely for its own sake and independently of any prospects of ex-

\footnotetext{
${ }^{5}$ Emotions in this sense may affect rational calculation but may also circumvent any rational calculations and dictate behavior altogether (Hanoch, 2002; Kaufman, 1999; Lobel \& Loewenstein, 2005, p. 1050).
}

ternal success" (Weber, 1964, p. 115). For the present research it is important to note that in situations of mass atrocities these beliefs are often incorporated in an ideology which can be seen as a system of beliefs (Alvarez, 2008, p. 216; D'Avray, 2010, p. 76). These goals, according to Weber, are pursued regardless of the personal costs it may entail and regardless of what the consequences of the course of action may be (Weber, 1964, pp. 116-117). The person acting out of a value rational orientation feels obliged to act in that matter to fulfill particular "demands" which he believes are required by "duty, honour, the pursuit of beauty, a religious call, personal loyalty, or the importance of some 'cause' no matter in what it consists" (Weber, 1964, p. 116). These goals will thus be pursued with incredible perseverance.

These two types of action are not mutually exclusive. Weber explains it is possible for a person to pursue a value rational goal by instrumental rational means (Weber, 1964, p. 117). In addition, Weber points out that behavior is seldom characterized by merely one type of social action but the analytical framework may serve as ideal types ${ }^{6}$ that allow us to ascertain which rationality predominated for a particular individual and how this impacted their behavior. Considering the important role that ideology plays in the perpetration of mass atrocities it is worthwhile investigating how these different types of rationalities underlay the behavior of Pol Pot and Milosevic and how it impacted their behavior. ${ }^{7}$ The theory of Max Weber will therefore be applied to assess which rationality dominated for Pol Pot and Milosevic by analyzing the lives and decisions of Pol Pot and Milosevic before they were faced with foreign intervention.

\subsection{Focusing on Pol Pot and Milosevic}

Not even undemocratic leaders are able to rule alone completely and they always require a small band of influential elite to maintain power (Ezrow \& Frantz, 2011, p. 82). The extent to which these confidants are able to shape and influence the decision making process, however, differs. In the case of Milosevic and Pol Pot, there is evidence that ultimately they were the ones making the decisions. In Cambodia, this holds true especially from 1976 onwards, at which point Pol had drawn all power to himself. Khieu Samphan, who was formally head of state but was actually a figurehead of Pol

\footnotetext{
${ }^{6}$ These ideal types according to Weber, are a "conceptually pure type of rational action... which has the merit of clear understandability and lack of ambiguity" and may be useful to assess "to which actual action is more or less approximated" (Weber, 1964, pp. 92, 117).

7 Max Weber's different types of rationality have earlier been applied to the war between Vietnam and Cambodia but from a cultural perspective, rather than one which focuses on the decision making process of the individual (Morris, 1999).
} 
(Chirot, 1994, p. 226; Short, 2004, p. 453), explains how the latter:

"would listen impassively and with immense patience to detailed reports from lower-level officials...[when he] reached a conclusion which satisfied him, he would make his decision, which then became irrevocable. Afterwards he would call a meeting [of members of the standing committee], explaining the problem before them in such a way that, without anyone realising it, the discussion was oriented towards the result he desired...Then he would announce his decision, making it appear that everyone contributed to its formulation. There was no vote. It was stated: 'The collectivity has decided'” (Short, 2004, p. 340).

Milosevic likewise was prone to take all the decisions himself and according to Cohen "his personal views dictat[ed] how all important issues would be resolved" (Cohen, 2006, p. 452; LeBor, 2003, p. 158). A close adviser of Milosevic for instance reportedly explained how "he practically does not need advisers...for in the end everything ends up as what he orders" (Cohen, 2006, p. 452). While each leader, therefore, relied on a small circle of confidants for power, they were ultimately in control of the most important decisions that needed to be taken.

\subsection{The Rationality of Pol Pot}

In order to assess what kind of rationality predominated Pol Pot's behavior it is important to look at his life story leading up to the war with Vietnam.

\subsubsection{The Younger Years}

Pol Pot was born as Saloth Sar in the village Prek Sbauv in a family of prosperous farmers (Chandler, 1999, pp. 7-8). During his school years, he was never really interested in politics (Chandler, 1999, p. 18; Short, 2004, p. 42) and his first steps along the ideological path seem somewhat disingenuous. He was first introduced to Communism when he was given a scholarship to study radio-electricity in Paris in 1948 (Kiernan, 1996, pp. 1011). These were the years when the French Communist movement had reached the zenith of its success, Stalin's personality cult had reached its peak, the Communists were victorious in China and the Korean War had started. As Chandler explains, Pol became a communist "when it was the popular thing to do" (Chandler, 1999, p. 25). Pol seemed unconcerned with his academic career during this time. Although he enrolled in the classes he never completed his examinations and thus lost his scholarship (Chandler, 1999, p. 26; Short, 2004, p. 50; 82). He was preoccupied with the communist movement and came to believe he needed to devote himself to the revolution. The works of Marx were too complicated for him to completely grasp, but he came to see communism as a way for good to triumph over evil (Short, 2004, pp. 65-66). Socialism and nationalism became intertwined in the minds of the young Cambodians and the purpose became to free Cambodia and turn it into a socialist utopia (Chandler, 1999, pp. 27-31; Short, 2004, pp. 52-58).

After his scholarship was revoked, Pol Pot decided to return to Cambodia to aid the revolution from there (Chandler, 1999, p. 40; Short, 2004, p. 82). Although in Cambodia Vietnamese patronage on the road to independence was resented (Chandler, 1999, pp. 90-91), Pol was not vehemently anti-Vietnamese in those years. A former class mate remembers him stating in 1954 that "the wheel of history" dictated that Cambodians be friendly with Vietnam "which is so much stronger" (Chandler, 1999, p. 45).

He returned to Cambodia having found his destiny and was utterly devoted to the struggle for independence and the socialist revolution (Chandler, 1999, p. 40) but was at this point in time more pragmatic on how this should be obtained and acknowledged that the help of the Vietnamese was indispensable.

\subsubsection{Rise to Power}

After the country gained independence in 1954, Pol worked as a teacher to cover up his clandestine party work (Chandler, 1999, pp. 43-53) until he is forced to flee to the eastern part of the country after Sihanouk's policies became more repressive. At this point in time he becomes a full time revolutionary (Becker, 1998, p. 11; Chandler, 1999, p. 63). The hardships he had to endure and the sacrifices he made in the next seven years were to harden his ideological zeal. After 1963 Pol met few non-believers which reinforced his self-assurance, his sense of destiny and his paranoia and belief that there were enemies undermining his plans (Chandler, 1999, pp. 64-65).

The prospects of winning the civil war through their guerilla tactics initially seemed bleak and living conditions were harsh; he suffered from malaria and at times needed to walk for days to a new settlement (Chandler, 1999, pp. 80-81, 89; Short, 2004, pp. 145, 172). In early 1970s, however, the tide was turning (Chandler, 1999, p. 85). By 1974 the communists had fought their way to the capital Phnom Penh and had started to create their communist utopia in the areas already under their control (Chandler, 1999, pp. 99-103).

\subsubsection{His Reign}

They eventually conquered Phnom Penh on April 17 1975. Within twenty-four hours the Khmer fighters evacuated the city, and drove its population into the countryside. Thousands died of exhaustion and malnu- 
trition (Chandler, 1999, pp. 1, 103-104). Pol Pot believed their radical collectivization efforts were necessary to achieve complete independence (Valentino, 2004, p. 134). This idea of self-reliance also meant that although the regime maintained friendly relations with China and the Republic of Korea, from whom they also accepted foreign aid, their relationship with the country's neighbors was hostile (Kiernan, 2001, pp. 193195). It was one of the primary reasons why Pol Pot wanted such a swift and thorough revolution. He believed that "if we run really fast, Vietnam won't be able to catch us" (Short, 2004, p. 293).

The project to reform the country had a prominent racial component and was oriented against minorities, especially the Vietnamese, and seen as part of the ancient struggle between Cambodia and Vietnam (Edwards, 2004, p. 62; Kiernan, 2001, pp. 193-194). The Khmer Rouge viewed Vietnam as alien and domineering and determined to take over their country (Turley \& Race, 1980, p. 96). Traitors were defined as "Khmer bodies with Vietnamese minds" that had to be eliminated (Kiernan, 2001, p. 192)

Pol Pot purged his own party from those he believed were obstructing the revolution and the victims included many who had been close to the leader for years (Becker, 1998, p. 202; Quinn, 1989b, pp. 197204). Pol Pot saw "a sickness in the party", stating, "we cannot locate it precisely. The illness must emerge to be examined" but believed that enemies "have been entering the party continuously-perhaps only one person, or two people, they remain" (Chandler, 2008, pp. 267-268) and he sought to eliminate them all. He believed any disagreement to be treacherous (Chandler, 2008, p. 266) and was never prepared to examine the feasibility of his policies, but considered any failings to be the work of traitors (Becker, 1998, p. 192; 201).

In order to recreate the great nation that Cambodia had once been, the Khmer Rouge under the leadership of Pol Pot held on to a totalistic philosophy that dictated that the goals should be achieved "at all costs" (Jones, 2006, pp. 185-186; Kiernan, 2001, pp. 194-195; Valentino, 2004, p. 137). Survivors remember how the phrase "keeping [you] is no gain, loosing [you] is no loss" became common, signaling how human lives were considered worthless (Chandler, 1999, p. 117).

\subsubsection{Conclusion: The Value Rational Leader}

Pol Pot stumbled upon the communist ideology rather unintentionally but his dedication to the cause was real. In Paris the seeds were sown for Pol's value rational orientation. However, during the early days of fighting, Pol was quite pragmatic and help from the Vietnamese Communists was seen as necessary to achieve their goals (Chandler, 1999, pp. 41-64, 89). In those early days, Pol was trying to achieve the value rational goal through instrumental rational means by cooperating with the Vietnamese. Throughout the struggle, his ideological zeal seems to have hardened. He was willing to pursue his utopian ideals even when this meant he personally had to endure hardships and the chances of success were slim. As he grew closer to his vision of a better and greater Cambodia, and made sacrifices along the way, his dedication grew stronger and his behavior grew more rigid. He was less willing to compromise and became convinced that everything needed to be done in accordance with the ideology, regardless of what the consequences were in terms of human life. He started to care less about the costs and consequences; an aspect of value rational action that would turn out to be detrimental for Cambodian society and eventually his own position of power.

\subsection{The Rationality of Milosevic}

When Max Weber's theory on the forms of rational social action is applied to the life of Milosevic a very different picture emerges and a much more pragmatic and opportunistic outlook becomes apparent.

\subsubsection{The Younger Years}

Milosevic was born on 20 August 1941 in Pozarevac Serbia in a region which had a loaded history because several important battles against the Turks were fought there and because it is the birthplace of the Chetnik resistence movement during WWII. There is no evidence, however, that Milosevic was particularly interested in the history or in Serb nationalist traditions early on (Sell, 2002, pp. 11-12; 72). His mother, who primarily raised him after his father abandoned the family, was a dedicated communist (LeBor, 2003, pp. 78). She has been described as ambitious, protective and dominant. She would push Slobodan to excel in school and would dress him up every day "in a fresh white shirt, like a junior version of the communist official she hoped he would be" (LeBor, 2003, p. 13). He became serious and well-mannered although he did not have many friends (LeBor, 2003, p. 13; Sell, 2002, p. 15). A class mate remembers that "even at that time it was clear to me that he was absolutely devoted to his personal ambitions" (LeBor, 2003, p. 14). During his years in high school he met his future wife Mira Markovic. Although the two undoubtedly loved each other, the relationship had a functional element as well since Mira's family was very well connected to the communist elite at the time (LeBor, 2003, pp. 16-21).

After high school he studied law at Belgrade University where it turned out he was a politician at heart, skillfully engaging in party politics (Doder \& Branson, 1999, p. 22; Sell, 2002, p. 19). During this time he struck up an intimate friendship with Ivan Stambolic and in the years after his studies, his career advanced rapidly because he continuously followed in the foot- 
steps of Stambolic (Doder \& Branson, 1999, pp. 25-26; Sell, 2002, pp. 24-25).

\subsubsection{Rise to Power}

In 1984, Milosevic became the head of the Belgrade Communist Party as Stambolic moved up to become the president of the Serbian league of communists (LeBor, 2003, p. 58; Sell, 2002, p. 25). When two years later he tried to follow Stambolic as well in becoming the head of the Serbian Communist Party, he only managed to do so because Stambolic threw his weight behind him (Stevanovic, 2004, p. 26). Throughout his rise to power he seemed to adjust his political message to the audience he was catering for. When he dealt with a more progressive audience or people from the West, he portrayed himself as a modernizer but within Yugoslavia, he maintained an appearance as a staunch conservative that stood up for Tito's legacy to maintain political support from especially the older generation (LeBor, 2003, pp. 66-69). This also became apparent when the SANU memorandum was leaked to the press. Stambolic outright rejected the document, but Milosevic started to ride the wave of nationalism, while claiming to remain true to communism. He denounced the memorandum in closed party sessions but refrained from doing so publicly, thus making both the nationalists and conservatives believe he was their ally (Doder \& Branson, 1999, p. 42; LeBor, 2003, p. 79). Throughout his career, Milosevic never stayed true to any particular ideology. He may have started out as a socialist but eventually it was his nationalist stance which helped to tear Yugoslavia apart (Kollander, 2004, p. 8).

When Milosevic started to use more Serbian nationalist rhetoric, fractures started to emerge in the alliance between Stambolic and Milosevic (LeBor, 2003, pp. 78-83). The final rupture occurred during the eighth session of the Serbian Communist Party where Milosevic betrayed his old friend, forcing Stambolic to step down after he was subjected to an extensive smear campaign in December 1987 (LeBor, 2003, p. 94; Vladisavljević, 2004, p. 196).

After he removed Stambolic from power, Milosevic replaced thousands of officials with his own loyalists and he launched his "anti-bureaucratic revolution" (LeBor, 2003, p. 101; Shigeno, 2004, p. 143). Bureaucracy became a catch all phrase to refer to enemies more generally that were defined through a Serbian nationalist lens (Shigeno, 2004, pp. 143-144). Organized rallies were held throughout the country and the protestors demanded their local leadership stepped down (Gagnon, 1994, p. 150). In 1988 and 1989 this was successful in Montenegro, Vojvodina and Kosovo (Gagnon, 1994, p. 150; Sell, 2002, pp. 81-83). Kosovo's autonomy was subsequently abolished in 1989 and after his speech in the same year, he did not visit the region for another six years (Sell, 2002, pp. 87, 94). Mi- losevic tried to employ similar tactics in Bosnia, Croatia and Slovenia but it caused a backlash; in the 1990 elections, parties which favored decentralization in Yugoslavia won, partly as a response to Milosevic staunch nationalist stance (Gagnon, 1994, pp. 150-153).

\subsubsection{His Reign}

It was widely believed Milosevic wanted to dominate all of Yugoslavia at this point but through his nationalist stance he inadvertently contributed to its downfall. After the Slovenes and Croats walked out of what would be the last meeting of the League of Communists, Milosevic was clearly upset when he saw his prospects of dominating Yugoslavia disappear (LeBor, 2003, p. 134; Sell, 2002, pp. 95, 104-105). Milosevic then quickly modified his goals; if he could not be Tito's successor and dominate the entire Yugoslavia, he would extend Serbia and at least dominate most of the old territory (Doder \& Branson, 1999, p. 63).

While the war against Slovenia was brief, Milosevic was unwilling to let Bosnia and Croatia go since they had large numbers of Serbs living in their borders. The wars there would be brutal and last until 1995. Milosevic showed little concern for the plight of his nation as LeBor points out; "the equation was simple enough; war ensured political power, political power demanded war" (LeBor, 2003, p. 146). He also needed the crises to deflect attention from the consequences that were the result of his own mismanagement (Post, 2004, p. 185).

Several demonstrations were organized in opposition to Milosevic's regime in the early 1990s. Milosevic responded by compromising and acquiescing to some of their demands or by coopting the opposition leaders (Doder \& Branson, 1999, pp. 77-79; 123-137; LeBor, 2003, pp. 161-163; 196-199). Milosevic throughout showed himself capable of compromise when this would ensure his hold on power, an attitude that also predominated when he decided to work towards peace in order to lift the sanctions that were imposed on his regime (Doder \& Branson, 1999, pp. 188-189; LeBor, 2003, pp. 219-220). As the consequences of the sanctions became more burdensome for Serbian society, unrest among the population started to rise which Milosevic saw as threatening to his continuing hold on power (Doder \& Branson, 1999, p. 176; LeBor, 2003, p. 220).

In the following years, Milosevic would abandon the Serbs living outside of Serbia. According to Doder and Branson, Milosevic at this time "showed his true colors, abandoning the national dream that had once stirred his people when he realized that it was an impediment to his rule" (Doder \& Branson, 1999, p. 212; Sell, 2002, p. 228). Milosevic stood by as the Serbs in the Krajina region were cleansed and did not even make arrangements for the thousands of refugees which consequently made their way into Serbia (Sell, 2002 , p. 242). He also turned his back on the Bosnian 
Serbs; after they repeatedly failed to accept peace plans, Milosevic broke off political and military relations and the media in Belgrade started to demonize them (Doder \& Branson, 1999, p. 199; LeBor, 2003, pp. 231-234). In addition, he remained passive when NATO started to bomb the Bosnian Serbs, and convinced them it had become necessary to start negotiations (LeBor, 2003, pp. 238-243, 262). According to Kollander, "Milosevic was ultimately convinced that it was in his best interest to abandon the Bosnian Serbs" (Kollander, 2004, p. 15).

As the Bosnian Serbs were losing territory fast, they succumbed to the pressure of letting Milosevic negotiate on their behalf but signed only reluctantly, under the threat of being arrested by Milosevic if they did not do so (LeBor, 2003, pp. 240-241; Sell, 2002, p. 254). The final agreement secured some of the most important elements for the Serbs, including the continuation of their name, Republica Srpska, but Milosevic also had made some surprising compromises, such as giving up Sarajevo (Doder \& Branson, 1999, p. 225; Sell, 2002, pp. 249-254). The Bosnian Serbs were discontent but Milosevic's propaganda campaign worked over time to hail him as a great peacemaker.

\subsubsection{Conclusion: The Instrumental Rational Leader}

Milosevic acted out of an instrumental rational orientation. His behavior was oriented to obtain discrete individual ends, namely to obtain and maintain power. The desire to obtain power and success was something Milosevic grew up with. His mother was the first women who pushed him to excel and after he met Mira, she further stimulated his ambitions. Growing up, the most important relationships he had also had a functional element to it and he was willing to betray his best friend when this served his best interest. His most important motivators throughout seem to have been success and power, never truly being devoted to any ideology. He grew up in an area that was important for Serbia's past but there is no evidence that this past was ever important for him. He was never a devoted nationalist or communist. He used a different ideological stance for different audiences and as one former associate explains, Milosevic "decides first what is expedient for him to believe and then he believes it" (Cohen, 2006, p. 439). According to Weber, when an individual acts on the basis of instrumental rationality, the expectations of others and the changing circumstances will be taken into account. In addition, the relative importance of the different aims is considered, allowing the individual to shift priorities when costs become too high. Milosevic hoped to dominate Yugoslavia in its entirety but when that was not possible, changed his plans to extend Serbia and rule most of it. Throughout he showed a willingness to compromise and shift his goals.

\section{The Intervention of NATO and Vietnam}

Pol Pot and Milosevic had different kinds of rationality predominate their decisions but the question remains whether, and if so how, this impacted the choices they made when they were confronted with the threat of military intervention. The two leaders stood at a crucial juncture in their rule when two much more powerful forces threatened to intervene militarily in response to horrendous human rights violations that their regimes had perpetrated in contentious border regions. In the next two sections it will be analyzed how the different types of rationality that predominantly guided the behavior of both of the leaders, influenced their response to these threats.

\subsection{Vietnam's Intervention and Pol Pot}

The war between Cambodia and Vietnam had been simmering for years before a final offensive, which was to remove Pol Pot from power, was undertaken by Vietnam. Throughout their time in power, the Khmer Rouge had violated the territorial integrity of Vietnam on numerous occasions (Burchett, 1981, pp. 145-162). By 1977 the conflict had escalated to the point where the Khmer Rouge were continuously carrying out large scale attacks against Vietnam. It was followed in April 1977 by a restrained counterattack on the part of the Vietnamese (Burchett, 1981, pp. 147-148). The Khmer Rouge, however, continued their attacks and refused to search for a peaceful resolution of the conflict (Burchett, 1981, p. 148).

The situation deteriorated further in the second half of the year (Burchett, 1981, p. 148). The attacks of the Vietnamese in December 1977 were the most severe to date, probably aimed at forcing Cambodia to come to a cease fire but Cambodia decided to break all diplomatic relations instead (Chandler, 1999, p. 142; Short, 2004, p. 377). Vietnam was surprised as the move made their skirmishes public and withdrew its troops on January 1st 1978 under the scrutinizing glare of the world. Cambodia saw it as a victorious moment but its troops had suffered many more casualties in comparison to the much stronger Vietnamese army. Convinced that Vietnam wanted to take over their country they began a "holy war" (Chandler, 1999, p. 143; Short, 2004, p. 378). Pol wanted to "smash them so that they are completely gone from our beloved land" where nothing but "piles of enemy's bones" would remain (Kiernan, 1996, p. 387).

Vietnam tried to initiate once more a peaceful solution on February $5^{\text {th }} 1978$. Its three-point plan stipulated that:

“1) An immediate end shall be put to all hostile military activities in the border region; the armed forces of each side shall be stationed within their 
respective territories, five kilometres from the border.

2) The two sides shall meet at once in Hanoi, or Phnom Penh, or at a place on the border, to discuss and conclude a treaty on mutual respect and a border treaty between the two countries.

3) The two sides shall reach an agreement on an appropriate form of international guarantee and supervision" (cited in Burchett, 1981, p. 160).

The Khmer Rouge never replied (Burchett, 1981, p. 161). Had Pol accepted it, he probably would have been able to cling to power but he was unwilling to let go of the aggressive stance he had taken thus far toward the Vietnamese. In the months that followed Cambodia took the violent initiative and committed gruesome crimes (Chandler, 1999, p. 143; Kiernan, 1996, pp. 388-389).

Pol Pot would argue that victory was inevitable as long as one Cambodian would be able to kill 30 Vietnamese:

"In terms of numbers, [each] of us must kill 30 Vietnamese...That is to say, we lose one against 30 . We will therefore need two million troops for 60 million Vietnamese. In fact, [that] will be more than enough....because Vietnam has only 50 million inhabitants...and we will still have six million Cambodians left. We must formulate our combat line in this manner in order to win victory...We absolutely must implement the slogan of one against 30 " (Short, 2004, p. 387).

By this time he was no longer concerned with the realistic prospects of success although he occasionally showed that he was aware of how gloomy prospects for victory were. At one meeting in August he said "We can hold on for a certain time...but if the present situation continues, it will become impossible. We can now afford to sustain only partial losses. If things go on as they are, we will face the risk of collapse." (Short, 2004, p. 388).

Early in January 1979 the Khmer Rouge were defeated and Pol Pot had to flee (Chandler, 1999, pp. 156-157). The final offensive made Vietnam a pariah state in the international community. China even launched a brief attack on Vietnam as a punishment for the invasion (Gordon, 1986-1987, p. 66; 71). Even though China had been unwilling to send a delegation of "volunteers" to Cambodia, it had given material support to the Khmer Rouge and was an ally of the regime (Chandler, 1999, p. 153; Gordon, 1986-1987, p. 69). When Pol Pot had to abandon Phnom Penh he believed he would manage to return to power, convinced the Vietnamese would perish in "a volcano of national indignation" (Short, 2004, p. 397). In these final moments he was remaining hopeful against his better judgment (Short, 2004, p. 397).

The goals that Pol Pot pursued, realizing his socialist utopia and safeguarding the country from Vietnamese domination were sacred and no compromises were possible, regardless of the costs this would entail for him personally. It is certainly possible to overestimate the psychological roots of the conflict over the geopolitical and economic factors but the hatred and determination of Pol Pot seems to have greatly exasperated the crisis (Chandler, 1999, p. 133).

\subsection{NATO's Intervention and Milosevic}

Like the war between Vietnam and Cambodia, the conflict in Kosovo had been brewing for years. Kosovo was never a primary concern for either the US or the European countries as long as the conflict did not escalate. At the same time, however, they feared that the situation could become highly destabilizing for the region if violence would spiral out of control (Daalder \& O'Hanlon, 2000, pp. 1, 9). The Bush administration, therefore, warned Milosevic already in 1992 that aggression against the Albanian Kosovars would lead to military intervention on the part of the US, in what was to become known as the Christmas warning. The Clinton administration would reaffirm the commitment of the US in 1993 (Daalder \& O'Hanlon, 2000, p. 9) but when Serbian violence against the Kosovar Albanians ensued, they did not follow through (Daalder \& O'Hanlon, 2000, p. 189). After Dayton, Washington felt it had lost its leverage over Milosevic as they feared taking a stance might endanger the fragile peace in Bosnia. If they had made a credible early threat of military action or sanctions, some argue it could have caused Milosevic to concede to NATO's demands, but the international community felt too reliant on Belgrade for the successful implementation of the Dayton accords (Daalder \& O'Hanlon, 2000, pp. 184-188).

In October 1998 Holbrooke, US' special envoy to the Balkans, managed to negotiate an agreement with Milosevic in which the latter consented to withdraw his troops and allow international monitors in the area (LeBor, 2003, pp. 281-282). It dampened the humanitarian disaster as it allowed humanitarian assistance into the region and permitted refugees to return during the harsh Balkan winter, but the agreement did not resolve the conflict and key details were ill defined and held in check by unarmed monitors (Daalder \& O'Hanlon, 2000, pp. 23; 59-62). The agreement was forged with Milosevic through a combination of threats and promises it would stave off more forceful military intervention (Crawford, 2001-02, p. 510; Daalder \& O'Hanlon, 2000, p. 47). The alliance, however, had no hold over the Kosovo Liberation Army (KLA) and when they exploited the "shift in balance" as Milosevic had 
expected, the latter started Operation Horseshoe that sought to have a broad region-shaped like a horseshoe-emptied of its Albanian inhabitants (Daalder \& O'Hanlon, 2000, pp. 58-59). The massacre at the village Racak became the symbol of the breakdown of the Holbrooke agreement (Roberts, 1999, p. 113).

At that time Milosevic did not take the prospect of NATO bombing very seriously (LeBor, 2003, p. 286). He was unsure whether it would happen at all, given the division among the NATO countries, but believed that even if NATO would actually bomb Serbia, his regime could withstand it and that it could possibly even boost his domestic support when Serbia's citizens rallied around the flag (LeBor, 2003, p. 287). After not following through when Milosevic violated the Christmas warning, once again NATO failed to act on the threat that bombing would occur if Milosevic did not comply with the cease fire. It was a pre-existing trend. Throughout the Yugoslav wars, threats had not been followed up with actions (Kaldor, 2006, pp. 64-66) and, Milosevic reckoned that a bombing campaign, if it would commence, would be "polite" (LeBor, 2003, pp. 286-287).

This was reflected in Milosevic' attitude during the Rambouillet negotiations that followed. He sent a low level delegation that was preoccupied with drinking heavily and singing patriotic songs (Daalder \& O'Hanlon, 2000, p. 79). When, however, the Serbs finally did seem serious in their effort to negotiate, the negotiators violated their own ground rules by amending the draft agreement at Serbian request (Daalder \& O'Hanlon, 2000, p. 81). It is likely this once more reinforced Milosevic' belief that NATO's ultimatums should be taken with a grain of salt and this was exacerbated by the fact that ground forces were openly ruled out (Daalder \& O'Hanlon, 2000, pp. 189-190).

NATO's bombings were eventually caused by the refusal of Milosevic to sign the Rambouillet Agreement. He feared that this would endanger his continued rule as signing the Agreement would mean that he would have largely given up Serbian hegemony in the area and there was no support among the population for such a decision (Hosmer, 2001, p. xii). He expected to be bombed as a result of it, but believed it would be brief and mild. He figured that the fragile alliance in NATO would not hold up when he showed that bombing would actually be counterproductive, that it would not stop the atrocities and he decided to increase the level of violence (Hosmer, 2001, p. xii). He, however, was wrong. NATO's determination actually hardened as the violence increased and, after initially rallying around the flag, it was the backing of his own support base that waned (Hosmer, 2001, pp. xiii-xiv). Milosevic started fearing for his own position and eventually became willing to negotiate when he believed NATO was prepared to execute more severe bombing raids, launch ground troops and when he realized Russia became less willing to protect the country diplomatically (Daalder \& O'Hanlon, 2000, p. 5; Hosmer, 2001, pp. xiii-xxiv).

Milosevic was willing to settle because it allowed him to maintain what was most important to him; power. What Milosevic did to the best of his capabilities is to calculate what was in his own best interest to do. He tried to take the ends, the means and the secondary results rationally into account and weigh them, indicating he acted on the basis of instrumental rationality. He thought about the alternative means to the end but miscalculated when he thought that increased ethnic cleansing would demoralize NATO. When thinking of the relationship between the end and the secondary consequences, he found that the risk for ground troops had become too high and finally decided that, as he was thinking of the relative importance of the different possible ends, power was more important to him than winning the war over Kosovo.

\section{Conclusion}

Often when atrocities are perpetrated, the dictator plays a crucial role in creating the environment in which these crimes become possible. He incites and legitimizes them and sets up the institutional structure that is necessary for their perpetration. The leader therefore should be an important element in strategies to prevent such crimes. Not every leader, however, is alike. While ideology almost always plays an important part in this process, not every dictator wholeheartedly believes in the ideology he propagates. The extent to which he is truly committed to the ideology, impacts the leader's responsiveness because a different type of rationality may actually be dominating his behavior than the (bounded) instrumental rationality, which is usually assumed to determine his reaction.

History has often shown that the creation of a utopia for a country may result in horrifying atrocities that are difficult to stop or prevent. Some goals are too important to sell out, leading to a total disregard of foreign policy threats to stop the crimes that are deemed necessary by the dictator for realizing the all-important goal. This should not be interpreted unequivocally as irrational behavior. A dictator that acts out of a value rational orientation will be more inclined to disregard the consequences of his policies. He will follow a course of action because he believes it to be the right thing to do, taking for granted any costs that may follow. In this manner the type of rationality that underlies the behavior of a dictatorial leader may be an important element in determining the responsiveness of a dictator to foreign policy measures.

The debate about rationality in international politics should move beyond cognitive limitations on rational behavior to also consider differences in the kind of rationality that dominates a person's behavior. Weber's different types of rationality could help to nuance 
and understand the relationship between rationality and foreign policy by not only placing a focus on cognitive limitations but also on the role ideology plays in rational behavior.

The instrumental rational leader will be more calculating and thus more receptive to foreign policy incentives or disincentives from other countries. Nevertheless, this does not mean that his behavior will conform to what can be considered objectively as the most beneficial course of action for him. Human errors and cognitive limitations remain important limitations to rational considerations. It is therefore important for the third party to send unison messages that leave little room for misinterpretation.

\section{Conflict of Interests}

The author declares no conflict of interests.

\section{Acknowledgments}

The current research forms part of a PhD project that is supervised by Professor Alette Smeulers and Professor Tijs Kooijmans.

\section{References}

Alvarez, A. (2001). Governments, citizens and genocide: A comparative interdisciplinary approach. Bloomington: Indiana University Press.

Alvarez, A. (2006). Militias and genocide. War Crimes, Genocide \& Crimes Against Humanity, 2, 1-33.

Alvarez, A. (2008). Destructive Beliefs: Genocide and the Role of Ideology. In A. Smeulers \& R. Haveman (Eds.), Supranational criminology: Towards a criminology of international crimes (Vol. 6, pp. 213-232). Antwerp: Intersentia.

Bazyler, M. J. (1987). Reexamining the doctrine of humanitarian intervention in light of the atrocities in Kampuchea and Ethiopia. Stanford Journal of International Law, 23(2), 578-620.

Becker, E. (1998). When the war was over: Cambodia and the Khmer rouge revolution. New York: Public Affairs.

Bellamy, A. (2001). Reconsidering Rambouillet. Contemporary Security Policy, 22(1), 31-56.

Bieber, F. (2002). Nationalist mobilization and stories of Serb suffering: the Kosovo myth from 600th anniversary to the present. Rethinking History, 6(1), 95-110.

Brosse, R. d. I. (2003). Political propaganda and the plan to create "a state for all Serbs:" consequences of using media for ultra-nationalist ends. ICTY Expert Reports: ICTY.

Burchett, W. (1981). The China Cambodia Vietnam triangle. Chicago: Vanguard Books.

Byman, D. L., \& Pollack, K. M. (2001). Let us now praise great men: Bringing the statesman back in. International Security, 25(4), 107-146.

Chandler, D. (1979). The tragedy of Cambodian history. Pacific Affairs, 52(3), 410-419.

Chandler, D. (1998). Cambodia's historical legacy. Accord, 5, 12-19.

Chandler, D. (1999). Brother number one: A political biography of Pol Pot. Bankok: Silkworm Books.

Chandler, D. (2008). A history of Cambodia. Boulder: Westview Press.

Chirot, D. (1994). Modern tyrants: The power and prevalence of evil in our age. New York: The Free Press.

Chirot, D., \& McCauley, C. (2010). Why not kill them all? The logic and prevention of mass political murder. Princeton: Princeton University Press.

Cohen, L. J. (2006). The Milosevic dictatorship: Institutionalising power and ethno-populism in Serbia. In B. J. Fischer (Ed.), Balkan strongmen: Dictators and authoritarian rulers of Southeast Europe (pp. 425-478). London: Hurst Company.

Crawford, T. W. (2001-2002). Pivotal deterrence and the Kosovo war: Why the Holbrooke agreement failed. Political Science Quarterly, 116(4), 499-523.

Daalder, I. H., \& O'Hanlon, M. E. (2000). Winning ugly: NATO's war to save Kosovo. Washington, D.C.: Brookings Institution Press.

D'Avray, D. L. (2010). Rationalities in history: A Weberian essay in comparison. Cambridge: Cambridge University Press.

Doder, D., \& Branson, L. (1999). Milosevic: Portrait of a tyrant. New York: The Free Press.

Edwards, M. (2004). The rise of the Khmer Rouge in Cambodia: Internal or external origins? Asian Affairs, 35(1), 56-67.

Eisen, A. (1978). The meanings and confusions of Weberian "rationality". The British Journal of Sociology, 29(1), 57-70.

Ezrow, N., \& Frantz, E. (2011). Dictators and dictatorships: Understanding authoritarian regimes and their leaders. New York: Continuum.

Fawthrop, T. (2005). The secrets of S21. Index on Censorship, 34(1), 78-81.

Fein, H. (1995). More murder in the middle: Lifeintegrity violations and democracy in the world, 1987. Human Rights Quarterly, 17, 170-191.

Fine, J. V. A. (2006). Strongmen can be beneficial: The exceptional case of Josip Broz Tito. In B. J. Fischer (Ed.), Balkan strongmen: Dictators and authoritarian rulers of Southeast Europe (pp. 269-317). London: Hurst \& Company.

Gagnon, V. P., Jr. (1994). Ethnic nationalism and international conflict: The case of Serbia. International Security, 19(3), 130-166.

Gordon, B. K. (1986-1987). The third Indochina conflict. Foreign Affairs, 65, 66-85.

Hagan, J. D. (2001). Does decision making matter? 
International Studies Review, 3(2), 5-46

Hanoch, Y. (2002). "Neither an angel nor an ant": Emotion as an aid to bounded rationality. Journal of Economic Psychology, 23(1), 1-25.

Harff, B. (2003). No lessons learned from the Holocaust? Assessing risks of genocide and political mass murder since 1955. The American Political Science Review, 97(1), 57-73.

Hermann, M. G., \& Hagan, J. D. (1998). International decision making: Leadership matters. Foreign Policy, 110, 124-137.

Hermann, M. G., Preston, T., Korany, B., \& Shaw, T. M. (2001). Who leads matters: The effects of powerful individuals. International Studies Review, 3(2), 83131.

Hinton, A. L. (1998). A head for an eye: Revenge in the Cambodian genocide. American Ethnologist, 25(3), 352-377.

Hosmer, S. T. (2001). The conflict over Kosovo: Why Milosevic decided to settle when he did. Santa Monica, CA: RAND Corporation.

Jackson, K. D. (1989). The ideology of total revolution. In K. D. Jackson (Ed.), Cambodia 1975-1978: Rendezvous with death (pp. 37-78). Princeton: Princeton University Press.

Jones, A. (2006). Genocide: A comprehensive introduction. New York: Routledge.

Jovic, D. (2001). The disintegration of Yugoslavia: A critical review of explanatory approaches. European Journal of Social Theory, 4(1), 101-120.

Jović, D. (2004). "Official memories" in post-authoritarianism: An analytical framework. Journal of Southern Europe and the Balkans Online, 6(2), 97-108.

Judah, T. (2009). The Serbs: History, myth and the destruction of Yugoslavia (3rd ed.). New Haven: Yale University Press.

Kaldor, M. (2006). New \& old wars: Organized violence in a global era (2nd ed.). Cambridge: Polity Press.

Kaufman, B. E. (1999). Emotional arousal as a source of bounded rationality. Journal of Economic Behavior \& Organization, 38(2), 135-144.

Kiernan, B. (1996). The Pol Pot regime. Race, power and genocide in Cambodia under the Khmer Rouge, 1975-79. New Haven: Yale University Press.

Kiernan, B. (2001). Myth, nationalism and genocide. Journal of Genocide Research, 3(2), 187-206.

Kiernan, B. (2010). The historiography of the Cambodian genocide. In D. Stone (Ed.), The historiography of genocide (pp. 468-486). New York: Palgrave Macmillan.

Kinne, B. J. (2005). Decision making in autocratic regimes: A poliheuristic perspective. International Studies Perspectives, 6(1), 114-128.

Kollander, P. (2004). The civil war in the Former Yugoslavia and the international intervention. In J. S. Morton, R. C. Nation, P. Forage, \& S. Bianchini (Eds.),
Reflections on the Balkan wars: Ten years after the break up of Yugoslavia. New York: Palgrave MacMillan.

Krain, M. (2000). Democracy, internal war, and statesponsored mass murder. Human Rights Review, 1(3), 40-48.

Kuper, L. (1981). Genocide: Its political use in the twentieth century. Harmondsworth: Penguin Books.

LeBor, A. (2003). Milosevic: A biography. London: Bloomsbury Publishing.

Lobel, J., \& Loewenstein, G. (2005). Emote control: The substitution of symbol for substance in foreign policy and international law. Chicago-Kent Law Review, 80, 1045-1090.

Marcus, G. E. (2000). Emotions in politics. Annual Review of Political Science, 3(1), 221-250.

McDermott, R. (2004a). The feeling of rationality: The meaning of neuroscientific advances for political science. Perspectives on Politics, 2(04), 691-706.

McDermott, R. (2004b). Political psychology in international relations. Ann Arbor: University of Michigan Press.

Mercer, J. (2005). Rationality and psychology in international politics. International Organization, 59(1), 77-106.

Midlarsky, M. I. (2005). The killing trap: Genocide in the twentieth century. Cambridge: Cambridge University Press.

Mintz, A., \& DeRouen, K. (2010). Understanding foreign policy decision making. Cambridge: Cambridge University Press.

Morris, S. J. (1999). Why Vietnam invaded Cambodia: Political culture and the causes of war. Stanford: Stanford University Press.

Morus, C. (2007a). The SANU memorandum: Intellectual authority and the constitution of an exclusive Serbian "people". Communication and Critical/Cultural Studies, 4, 142-165.

Morus, C. (2007b). Slobo the redeemer: The rhetoric of Slobodan Milosevic and the construction of the Serbian "people". Southern Communication Journal, 72(1), 1-19.

Mueller, J. (2000). The banality of "ethnic war". International Security, 25(1), 42-70.

Peang-Meth, A. (1991). Understanding the Khmer: Sociological-cultural observations. Asian Survey, 31(5), 442-455.

Post, J. M. (2004). Leaders and their followers in a dangerous world: The psychology of political behaviour. Ithaca: Cornell University Press.

Quinn, K. (1989a). Explaining the terror. In K. D. Jackson (Ed.), Cambodia 1975-1978: Rendezvous with death (pp. 215-240). Princeton: Princeton University Press.

Quinn, K. (1989b). The pattern and scope of violence. In K. D. Jackson (Ed.), Cambodia 1975-1978: Rendezvous with death (pp. 179-208). Princeton: Princeton University Press. 
Ramet, S. P. (2005). Thinking about Yugoslavia: Scholarly debates about the Yugoslav breakup and the wars in Bosnia and Kosovo. Cambridge: Cambridge University Press.

Regan, P. M., \& Henderson, E. A. (2002). Democracy, threats and political repression in developing countries: Are democracies internally less violent?. Third World Quarterly, 23(1), 119-136.

Renshon, J., \& Renshon, S. A. (2008). The theory and practice of foreign policy decision making. Political Psychology, 29(4), 509-536.

Roberts, A. (1999). NATO's "humanitarian war" over Kosovo. Survival, 41, 102-123.

Ron, J. (2000). Territoriality and plausible deniability: Serbian paramilitaries in the Bosnian war. In B. B. Campbell \& A. D. Brenner (Eds.), Death squads in global perspective: Murder with deniability (pp. 287312). New York: Palgrave MacMillan.

Rosati, J. A. (2000). The power of human cognition in the study of world politics. International Studies Review, 2(3), 45-75.

Rummel, R. J. (1994). Power, genocide and mass murder. Journal of Peace Research, 31(1), 1-10.

Sell, L. (2002). Slobodan Milosevic and the destruction of Yugoslavia. Durham: Duke University Press.

Shaw, M. (2007). The general hybridity of war and genocide. Journal of Genocide Research, 9(3), 461473.

Shigeno, R. (2004). Nationalism and Serbian intellectuals. Perspectives on European Politics and Society, 5(1), 135-159.

Short, P. (2004). Pol Pot: The history of a nightmare. London: Murray Publishers.

Simon, H. A. (1985). Human nature in politics: The dialogue of psychology with political science. The American Political Science Review, 79(2), 293-304.

Smeulers, A., \& Grünfeld, F. (2011). International crimes and other gross human rights violations: $A$ multi- and interdisciplinary textbook. Leiden: Martinus Nijhoff Publishers.

Staub, E. (1989). The roots of evil: The origins of genocide and other group violence. Cambridge Cambridge University Press.

Staub, E. (2000). Genocide and mass killing: Origins, prevention, healing and reconciliation. Political Psychology, 21(2), 367-382.

Staub, E. (2010). Overcoming evil. Oxford: Oxford University Press.

Stevanovic, V. (2004). Milosevic: The people's tyrant. London: I.B. Tauris.

Stewart, C. S. (2007). Hunting the tiger: The fast life and violent death of the Balkans' most dangerous man. New York: Thomas Dunne Books/St. Martin's Press.

Straus, S. (2001). Organic purity and the role of anthropology in Cambodia and Rwanda. Patterns of Prejudice, 35(2), 47-62.

Swidler, A. (1973). The concept of rationality in the work of Max Weber. Sociological Inquiry, 43(1), 35-42.

Takei, M. (1998). Collective memory as the key to national and ethnic identity: The case of Cambodia. Nationalism and Ethnic Politics, 4(3), 59-78.

Turley, W. S., \& Race, J. (1980). The third Indochina war. Foreign Policy, 38, 92-116.

Valentino, B. A. (2004). Final solutions: Mass killing and genocide in the twentieth century. Ithaca: Cornell University Press.

Varshney, A. (2003). Nationalism, ethnic conflict, and rationality. Perspectives on Politics, 1(1), 85-99.

Vickery, M. (1984). Cambodia: 1975-1982. Sydney: South End Press.

Vladisavljević, N. (2004). Institutional power and the rise of Milošević. Nationalities papers, 32(1), 183-205.

Wayne Nafziger, E., \& Auvinen, J. (2002). Economic development, inequality, war, and state violence. World Development, 30(2), 153-163.

Weber, M. (1964). The theory of social and economic organization (T. P. A.M. Henderson, Trans.). New York: The Free Press.

Womack, B. (2003). Asymmetry and systemic misperception: China, Vietnam and Cambodia during the 1970s. Journal of Strategic Studies, 26(2), 92-119.

Woodward, S. L. (1995). Balkan tragedy: Chaos and dissolution after the cold war. Washington, D.C.: The Brookings Institution.

Woolf, L. M., \& Hulsizer, M. R. (2005). Psychosocial roots of genocide: Risk, prevention, and intervention. Journal of Genocide Research, 7(1), 101-128.

\section{About the Author}

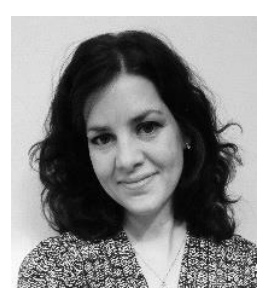

\section{Maartje Weerdesteijn}

Maartje Weerdesteijn is a PhD candidate at Tilburg University, Department of Criminal Law. She obtained a Master in International Crimes and Criminology from VU University Amsterdam (Cum Laude), a Bachelor in European Studies (Cum Laude) and previously worked as a lecturer at the Criminal Law and Criminology Department of VU University Amsterdam. 